\title{
article $\mid$ TRAFFICKING AND PROSTITUTION OF BRAZILIAN WOMEN IN PORTUGAL:

\author{
the journalistic discourse between the \\ stereotyping and the victimization
}

\author{
ESTER AMARAL DE PAULA MINGA \\ Universidade Nova de Lisboa, Lisbon - Portugal \\ ORCID: 0000-0002-0974-0369
}

DOI: 10.25200/BJR.v16n2.2020.1168

Received in: December 30th, 2018

Revised on: May $27^{\text {th }}, 2019$

Revised on: June $25^{\text {th }}, 2019$

Approved on: September $9^{\text {th }}, 2019$

\begin{abstract}
In the beginning of this century, the human trafficking received wide attention in Portugal, which developed several actions to reinforce the legislation in this area. Not by coincidence, this attention is contemporary with the consolidation of the country as a receiver place, which indicates its inextricable relation with migration phenomenon. In this article, we purpose to analyze the representation of human trafficking for sexual exploitation - one of the most prominent vectors of this criminal practice -, in the journalistic discourse about Brazilian women immigrant's prostitution. However, the Brazilian woman's image that emerged in the news about prostitution, following the "Mothers of Bragança" case, in 2003, privileged the stereotyping, put in the background issues about trafficking and exploitation (Correia, 2014). Analyzing some texts of Público and Expresso newspapers published during these years, we observe an erratic route which sometimes privileges a sensational tone, and sometimes pay attention to the exploitation and trafficking issues, reflecting in this way the inconsistency found in the law about the theme.
\end{abstract}

Key words: Brazilian immigrant women. Human trafficking. Journalism. Portugal. Prostitution. 


\title{
TRÁFICO E PROSTITUIÇÃO DE BRASILEIRAS EM PORTUGAL: o discurso jornalístico entre a estereotipia e a vitimização
}

\begin{abstract}
RESUMO - No início deste século, a problemática do tráfico de pessoas recebeu ampla atenção em Portugal, que empreendeu sucessivas ações de reforço legislativo neste âmbito. Não por acaso, esta atenção é contemporânea à consolidação do país como local de acolhimento, o que indica sua relação inextricável com o fenômeno migratório. Neste artigo, propomo-nos a analisar a representação do tráfico de pessoas para fins de exploração sexual - um dos vetores mais pronunciados desta prática -, a partir do discurso jornalístico sobre a prostituição de imigrantes brasileiras. Todavia, a imagem da brasileira que emergiu das reportagens sobre prostituição, em seguimento ao caso "Mães de Bragança", em 2003, privilegiou a estereotipização, pondo em segundo plano a questão do tráfico e da exploração (Correia, 2014). A partir da análise a algumas peças dos jornais Público e Expresso ao longo destes anos, observamos um percurso errático em que ora se privilegia a linguagem sensacionalista, ora se enfoca a questão da exploração e do tráfico, refletindo assim a inconsistência verificada na legislação devotada ao tema.

Palavras-chave: Imigrantes brasileiras. Tráfico humano. Jornalismo. Portugal. Prostituição.
\end{abstract}

\section{LA TRATA Y LA PROSTITUCIÓN DE BRASILEÑAS EN PORTUGAL: el discurso periodístico entre los estereotipos y la victimización}

RESUMEN - A principios de este siglo, el problema de la trata de personas ha recibido amplia atención en Portugal, que libró sucesivas acciones de fortalecimiento legislativo en la materia. No por casualidad, esta atención es contemporánea a la consolidación del país como lugar de acogida, lo que indica su relación inextricable con el fenómeno migratorio. En este artículo nos proponemos analizar la representación del tráfico de personas con fines de explotación sexual - uno de los vectores más pronunciados de esta práctica -, a partir del discurso periodístico sobre la prostitución de inmigrantes brasileñas. Sin embargo, la imagen de la brasileña que emergió de los reportajes sobre prostitución, en seguimiento al caso "Madres de Bragança", en 2003, privilegió la estereotipización, poniendo en segundo plano la cuestión del tráfico y de la explotación (Correia, 2014). A partir del análisis a algunos textos de los periódicos Público y Expresso a lo largo de estos años, observamos una ruta errática en que por veces se privilegia el lenguaje sensacionalista y por veces se enfoca la cuestión de la explotación y del tráfico, reflejando así la inconsistencia verificada en la legislación dedicada al tema.

Palabras clave: Inmigrantes brasileñas. Tráfico humano. Periodismo. Portugal. Prostitución.

\section{Introduction}

Human trafficking is the third largest criminal activity in the world, with sex trafficking accounting for two thirds of this crime industry's profits. Since the turn of the twenty-first century Portugal has been trying to criminalize human trafficking and its active agents; however, irregular legislation on prostitution (inherent to human trafficking) has made it difficult for agents of the law to 
understand what constitutes human trafficking (Santos et al., 2009) and, as we hope to demonstrate in this article, what the framework of journalistic discourse is on the two interrelated issues.

In terms of journalistic representation, not only is the discourse surrounding human trafficking confusing, probably due to the fact that legislation does not define prostitution as a crime but only its exploitation by others (for example, pimping), coupled with the understanding that consent of the trafficked person is irrelevant, which does not exempt anyone from criminal charges. This issue is also rife with stereotypes on the Brazilian nationality; the one most often related to trafficking and prostitution in Portugal. According to data from the latest report on human trafficking from the US Department of State (2019)' ${ }^{1}$, it is mainly Portuguese, African and Eastern European women and children who are victims of sexual trafficking in the country; however, the beginning of this century paints a different picture.

According to Boaventura Sousa Santos, Conceição Gomes and Madalena Duarte (2009), there was predominance of Brazilian women in the sexual market in Portugal, a phenomenon commonly related with social exclusion and insecurity which could, at any given time, easily lead to situations of sex trafficking. Despite the most recent data, both Dália Rodrigues, the technical director for the $O$ Ninho institute, and Maria Magdala, president of the ComuniDária association, agree that the majority of women they work with are Brazilian².

In that regard, we decided to take a closer look at the journalistic discourse on human trafficking by examining accounts and stories of the prostitution and sexual trafficking of Brazilian immigrants. Aside from the prevalence of Brazilians in the Portuguese sex market (and probably also because of it), Portugal has been producing images that accentuate the supposed innate sexuality of Brazilian women since colonial times (Machado, 2003; Padilla, 2007; Feldman-Bianco, 2001; among others). This representation, coupled with the empirical evidence showing that it is mostly Brazilian women who are involved in the prostitution and human trafficking that occurs in Portugal, has led to a number of reports on Brazilian immigration being published in the beginning of the 21 st century, most of which tend to focus on the prostitution and trafficking.

João Carlos Correia (2014) cites a study by the High Commission for Migration and Ethnic Minorities (a Portuguese government institution) in 2003 which found that, out of the 224 
news reports which focused on immigration and ethnic minorities, 48 of them addressed prostitution in some form, with Brazilian women being referenced the most. It was also observed that the majority of those reports on Brazilian immigration focused on the trafficking of women and used tabloid-style language to describe gender stereotypes associated with tropical countries yet hardly covered the human slavery so often related to immigration.

The emphasis placed on stereotypes may have contributed to the generalization that exists around the stigma of prostitution and the number of Brazilian immigrant women in Portugal (Santos et al., 2009), however, this image has also been galvanized by the enormous repercussion of the "Mães de Bragança" (Mothers of Bragança) movement. This movement was significant because it symbolically and temporally demarcated journalistic coverage on the prostitution of Brazilian immigrant women. It was created by women from the city of Bragança, in the north of Portugal, who wanted to expel the Brazilian prostitutes from the city for allegedly seducing their husbands. The "Mothers of Bragança" movement led to intense media coverage, not only within Portuguese media, but also internationally, as it made the cover of Time magazine in October 2003 (Pais, 2010). According to Correia (2014), the movement became an ideal example of the xenophobia and gender stereotypes that exist in media, as well as being the first example for discussing media discourse about Brazilian women.

Correia notes a positive evolution in the journalistic coverage of a similar controversy ten years later (prostitution in the Quinta do Grilo neighborhood of Viseu, a city in the center region of Portugal). The coverage in 2013 differs from the sensationalism and markedly populist tone of reports from the previous decade as it looks at other angles of the issue such as the widespread prostitution among the country's illegal immigrant population and the fact that pimping is a crime in Portugal. However, this is not the impression we got from texts on the prostitution of Brazilian immigrants published in two of the country's leading newspapers Público and Expresso, between the years $2000-2005$ and $2010-2015$.

We chose these two time periods because the first one reflects the aforementioned increase in public interest for the problem of human trafficking and is concurrent with the second wave of Brazilian immigration in Portugal. The second one we chose because it reflects a time when the country's Brazilian community declined as a result 
of the economic crisis. Using critical discourse analysis and framing analysis to analyze these texts, we noticed that the discourse from both newspapers on the prostitution of Brazilian immigrants alternates between a stereotyped representation of the exploitation of these women - some of which may be characterized as sex trafficking and a victimization representation which removes the autonomy from those women who have chosen particular life paths.

These analysis methods were chosen based on our belief that only a more detailed analysis, and not just the semantic one, of the structures of discourse (their rhetorical, stylistic and syntactic aspects, in particular) can fully reveal how the Other - in our case, the Brazilian immigrant women in texts on prostitution and sex trafficking - is represented in the discourse. As Teun A. van Dijk explains (2002), journalistic discourse consists of a specific type of text whose meaning is conveyed through the textual structures, but which also acknowledges the sociocultural and cognitive context of the audience, considering how it relates to the narrated fact and the way discourse dialogues with the background.

Therefore, before analyzing the texts we shall discuss the evolution of Portuguese legislation on prostitution and human trafficking, and the social representations of Brazilian women. The objective is to understand the differing discourse about the prostitution of Brazilian women present in the newspapers, something related not only with the common images about these women popularized since the discovery of Brazil, but also with divergent points of view on sex work, which range between abolitionists, prohibitionists and regulationists - and the very inconsistency of the laws regulating it.

We would like to mention that the texts from both newspapers were selected manually and a more in-depth analysis was conducted on those which addressed prostitution/sex trafficking more extensively. Nevertheless, the texts we analyzed for this paper are not representative of all the texts covering this subject, and we are aware that there are some texts we may have missed, but they do provide a fairly thorough overview.

\section{Legislation}

Prostitution has been illegal in Portugal since the 1960s, but the 1982 Penal Code decriminalized the practice while maintaining 
the illegality of prostitution exploited by others; for example, pimping. The code also criminalizes human trafficking, however, it was only through the approval of the Additional Protocol to Prevent, Suppress and Punish Trafficking in Persons, especially Women and Children in 2004 (adopted by the United Nations [UN] in 2000 and referred to as the Palermo Protocol) that the illegality of this practice acquired the characteristics it currently possesses.

The understanding of human trafficking was further strengthened in 2007 with the National Plan against Trafficking in Human Beings (2007-2010), adopted by the resolution of the Portuguese Council of Ministers, concurrent with the publication in the same year of a new Immigration Law. In 2008, Portugal established a Decree Law to create the Observatory on Trafficking in Human Beings (OTSH).

What remains of the various measures adopted at the beginning of the twenty-first century is the irrelevance of the consent of the victim. As noted on the OTSH website $^{3}$, this should not be considered if any of the following means of trafficking people are used: violence, abduction, serious threat, abuse, deception, fraud or a position of vulnerability. According to Rita Basílio Simões (2018), these measures correspond to a punitive approach followed by the Portuguese state when it expanded the range of criminal actions defined as human trafficking.

However, human trafficking in terms of sexual exploitation is a complex situation in Portugal which generates different viewpoints and understandings as it deals with the fact that prostitution is not a crime, but pimping is. As Santos et al. (2009) explain, during negotiations for the approval of the Palermo Protocol, it was determined that forced prostitution fit the proposed definition of human trafficking, but there was no agreement on whether prostitution in general fell under that definition. This meant that prostitution was defined differently from country to country, which led to distinct understandings, like in Sweden where procuring sexual services is a crime and in the Netherlands where prostitution has been decriminalized and is regulated by the country's labor laws. "If the protocol tends to be unanimous in its definition, it does not take a stand on the relationship between trafficking and prostitution, nor does it clearly define the terms 'sexual exploitation' and 'prostitution"' (P. 80).

The inseparable relationship between sex trafficking and prostitution requires each state to create policies aimed at combating trafficking. However, as Duarte (2012) points out, there 
are different interpretations concerning the ideal legal-normative order of prostitution, ranging from complete criminalization to regularizing it as a form of work. Despite the consensual disapproval of sex trafficking, feminist groups differ in their understanding of prostitution; some see it as an unambiguous form of exploitation and violence while others see it as a legitimate individual decision.

As Simões (2018) explains, the decriminalization of prostitution and the penalty for its exploitation correspond to the abolitionist view, which complies with the political-legislative framework of most European countries. The perspective, although it considers prostitution as a form of slavery, differs from the prohibitionist view in terms of the means adopted to combat it, since it criminalizes all agents involved in its practice (covered by Portuguese legislation until 1982). Now the regulatory view, adopted by countries such as Germany and the Netherlands, considers prostitution an acceptable practice that must be regulated by the state. The range of interpretations, not always clearly translated in legislation, contributes

to the persistence of difficulties in various countries with regard to identifying victims of trafficking in the day-to-day work of the police, legal actors, and social workers among others [...]. (Duarte, 2012, p.258).

In regards to the situation of Brazilian immigrants in Portugal, Santos et al. (2009) note that what generally happens is that most women give their consent and are conscious of the reason they came to the country, but end up getting involved in strong exploitation which may be characterized as sex trafficking. What's more, the groups which they assimilate with usually have a kind of informal, almost artisan-like structure to them which are often made up of the victims' friends, relatives and colleagues.

This situation led to a social consensus where the prostitution of Brazilian immigrant women was considered more a labor choice and not so much a form of exploitation and violence, even though there are some cases that concur with the crime of sex trafficking. Santos et al. (2009) became aware of this consensus mainly from their consultations with police officers, yet we also identified the central discourse of some journalistic pieces which, despite describing situations that could be characterized as pimping or trafficking, do not see them as such.

In this sense, apart from considering the particularities of what the standard situation regarding the trafficking of Brazilian 
women for prostitution is, we must also consider the whole range of images that the Portuguese social imagination has of Brazilian women, especially how it tends to exacerbate their sexuality and portray them as having an innate sensuality.

\section{The image of Brazilian women}

The image of Brazilian women is described as one of innate sensuality and great sexual passion, not only is this an image that circulates in Portugal, but it is a social representation also shared by other countries (Padilla, 2007). This is largely due to the fact that Brazil itself has historically promoted a certain image of national identity, one which highlights the sensuality of its women, in particular its "mulatto" women, which the country subsequently exploited for the purposes of promoting tourism.

In reference to Portugal, Igor José de Renó Machado (2003) notes that there are two sources of stereotypes about Brazilian women: one that comes from Brazil and the other from Portugal, the latter having reshaped its image about the country and its population since the colonial period. We say that these two sources have historically fed off one another because, as Stuart Hall (1990) says of the cultural identity of colonized peoples, the colonizer's governing representations become a considerable and inherent part of that country's cultural identity. Even though that identity is not unchangeable, it is inherent and tends to get re-appropriated and reworked in different forms.

Within these governing representations, colonized subjects were represented as the "Other" - objectifiable and individual, despite their plurality of origins. According to the categories of knowledge of Western thought, however, these representations, as a system of power and not just knowledge and/or classification, made colonized peoples see and perceive themselves as this Other. Francisco Bosco (2017) analyzes the reworking of representations in terms of the glorification of nature present in the Brazilian national narrative, built after gaining its independence and in response to the material and institutional precariousness in which the country existed.

However, the joyous image of nature had already appeared in European narratives about the American continent, when it emerged as the inaugural sign of its discovery in the letter of Américo Vespucci 
and the Letter of Pêro Vaz de Caminha in Brazil. "And it is graceful in such a way that, wanting to enjoy it, everything will be given her, for the sake of the waters it has" (as cited in Bosco, 2017, p.195).

The celebration of nature was institutionalized in 1922 through the national anthem with verses such as "enormous in nature" and "mirrors this greatness", an attempt to relate the greatness of the nation as an institutional space with its geographical magnitude, and was established throughout the 20th century in the popular song. It also corresponds with the first time that the image of Brazil went international with Carmen Miranda and her iconic fruit hats.

However, the idea at first was to relate a real, physical greatness with an institutional one. Over time the popular song began to associate this greatness of nature to a singular Brazilian culture.

The "good and delicious land", relaxed, welcoming, rhymes with the "sestrosa / indiscreet-looking brunette" and reflects on it.The exuberance of the fruits on Carmen Miranda's head mirrors her vibrant, sensual figure, full of vitality and body, without repressing the sexual drives that mark the aggravated unease of the most intensively productivist nations. (Bosco, 2017, p.35).

But, as Camila Craveiro and Cláudia Carvalho (2017) point out, even this attempt in the Old World to contrast the sensual exuberance of Brazilians (especially Brazilian women) with sexual repression was not at all original, as the following excerpt about the indians taken from the Letter of Caminha shows:

There were three or four young women among them, quite young and kind, with dark black hair, long and shoulder-length, and their shame so clean that we were not ashamed to look at them. [...] And one of those girls had her body dyed; and she was so well done and so complete, and her shame (which she did not have) so graceful that many women of our land, seeing her features, would feel ashamed that they did not look like her. (as cited in Craveiro \& Carvalho, 2017, p.67).

So, by looking at the Brazilian cultural identity that was established throughout the twentieth century, not only did we identify the sensuality attributed to Brazilian women, but we also identified a kind of feminization of the country's image, of noticeable European influence. The dialogue between refusing and recognizing this European/colonizing influence was successful culturally-speaking because it established a powerful, artistic expression of mixed race peoples, yet placed the Brazilian woman on a pedestal (especially "mulatto" women) and painted them as a portrait of sensuality and 
exuberance which eventually reified the European representation of native peoples.

The contribution of Brazilian sociologist Gilberto Freyre's Casa-grande \& senzala (1933/2003) unquestionably helped towards consolidating this narrative of a tropical, exotic and mixed race country in Brazilian popular culture. His book focuses on what he saw as the specific nature of Portuguese colonization and the predisposition of its people for "overseas adventures", constituting multiracial societies, and the interpenetration of values and customs (Castelo, 1998). Bosco's (2017) idea of the Freyrean concept of multiracial societies to explain Brazilian reality is that the particular case of sex was imposed on the ideologies of race, but did not dissolve them. Freyre discusses the formation of the colony in the following excerpt:

\begin{abstract}
Mingling delightfully with women of color upon first contact and producing mixed race children, only a few thousand bold males owned vast expanse of land and competed with numerous and great peoples regarding the extension and success of colonial possessions. (Freyre, 2003, p.70).
\end{abstract}

However, the Freyrean thought also had impact on the Portuguese social reality, especially in the second half of the twentieth century. As J. M. Brandão de Brito and Fernando Rosas explained (1996), the end of World War II led to a crisis in the European colonial system, and a few years later led to the near total decolonization of Africa and Asia. Portugal, as a way of circumventing this unfavorable international circumstances, abandoned the imperial conception embodied in the Colonial Act (reformulated in 1951) and adopted lusotropicalism - a theory developed by Freyre - as official doctrine. Valuing the supposed ability of the Portuguese to relate to the peoples of the tropics was as ideologists of the New State imagined - the fundamental difference between Portuguese and Northern European colonialism.

In this context, Brazil emerged as an ideal colony as it was the most successful example of constituting multiracial societies in the tropics. We wonder whether adopting lusotropicalism and disseminating their ideas through propaganda instruments did not crystallize, in the Portuguese social imagination, the image of men as being sexually attracted to women from the tropics and their innate sensuality.

Bela Feldman-Bianco (2001) notes that during the 1980s (the first wave of Brazilians immigrating to Portugal), with a large number of Brazilians entering the labor market, the Portuguese updated and recreated their chauvinist and racist stereotypes to include the notion of 
ginga (a term used to describe the movement of the body, particularly a woman's body while dancing) and "tropical sensuality", seen as an innate trait of "mulatto" women. These stereotypes led to a number of images of/about Brazil in Portugal which, at that time, were mostly spread through soap operas and the so-called "Brazilian culture" or "Brazilian theme nights" in nightclubs. This consumption of "Brazilian culture" was directly influenced by Freyre's interpretations of the nation.

José Machado Pais (2005) understands the impact soap operas have had on the Portuguese social reality by observing how, for more than four decades, Portugal lived under a conservative dictatorship in which, despite valuing the image of the virile Portuguese man, domestically imposed a strong moral restraint on sexuality. When television began to broadcast soap operas in the 1970s, many of the scenes were considered suggestive and, as Isabel Ferin Cunha points out (2005), were seen as examples of cultural and sexual transgression rather than being perceived as conveying emancipatory models of females.

Cunha goes further and talks about the influence that three decades of soap operas have had on the Portuguese view of Brazilian immigrant women (which can be seen in the "Mothers of Bragança" case and the intense coverage it received), and how their representation on television news was also influenced by a soap opera style of narrative. "In the images of prostitution, the object of desire is covered up using technical and scenic resources that hide the characters and display the most coveted body parts [...]" (Cunha, 2005, p.550).

It should be noted that despite the historical focus on the sexuality of "mulatto" women, the phenotypic differences tend to be blurred in transnational situations such as those experienced by Brazilian immigrant women in Portugal. As Adriana Piscitelli explains (2008) from the concept of intersectionalities, whether Brazilian women are considered white or dark in Brazil, they are racialized as mestizos in Clobal North countries (not just Portugal) and this racialization is sexualized.

Portugal has the general idea that Brazilians are always partying and in a good mood; however, they consider Brazilian men to be lazy and cunning, while the women are seen as hot, vivacious and easy (Padilla, 2007).

We use the term stereotype in this article as it is presented by Walter Lippmann in his classic book Public Opinion (1922/1998), in 
which he explains that because the surrounding reality is too complex to differentiate specificities from generalities, stereotypes emerge as the result of a cognitive energy-saving process in which we tend to adhere to the definitions of the culture which we are immersed in and perceive it in its stereotyped form. This helps us understand how (based on the range of images produced in Portugal since the colonial period) highlighting the sensual character of Brazilian women at the same time that a number of reports on prostitution and immigrant trafficking at the beginning of the century were published has renewed the stereotype.

In this sense, we refer not to a secular production of images about Brazilian women, but to a constant renovation of them over the centuries, where the stress on sexuality and exoticism remains a constant. This also leads us to Serge Moscovici's theory of social representation (1988) which emphasizes the communicational aspect (of a dialogical and media nature) in our cognitive process of understanding reality, resulting in ideas/images taken as common sense.

In other words, stereotypes, in correlation with social representations, correspond to individual thoughts and ideas which then become social thoughts/ideas through communicational processes. However, they are not completely original, so one of the ways in which a social representation is established is from a process called anchoring, in which a new phenomenon is given meaning by associating it with an older, similar social representation. In this sense, it is assumed that the social process gives rise to the metonymization of the image of Brazilian immigrant women as prostitutes, an image that is depicted in a number of news reports on prostitution at the beginning of the century, but also contains old social representations of Brazilian women, for example, the ones contained in the Letter of Pêro Vaz de Caminha that sexualize the natives.

Lastly, we would like to point out something both authors have in common: their underlying reference to the concept of ideology, which in their readings is described as common sense or ideas taken for granted from groups or societies. Teun van Dijk also recognizes the establishment of social representations:

[...] the ideologies of dominant groups control the development of SR [social representations], the formation of models, the production of action and the discourse of group members in such a way that the group will retain power and reproduce its hegemony over dominated groups, as has been most obvious in the cases of classism, sexism and racism. (van Dijk, 2005, p.113). 
This is how we understand the secular production of social representations of Brazilian women in Portugal, based on an ideological bias of a Eurocentric and colonial profile.

\section{Methodology}

At the beginning of the twenty-first century Portuguese media prioritized sex trafficking and prostitution when reporting on the Brazilian community (Correia, 2014) and, also in the early years of this century, established a common view of Brazilian immigrant women, particularly one associated with prostitution. We collected all the pieces published by the Público and Expresso newspapers between the years 2000-2005 and 2010-2015 that presented the themes of prostitution and sex trafficking of Brazilian immigrants.

The decision to use these newspapers is warranted because, although they represent only a small portion of the total number of reports on these themes during the selected time periods, they are referenced newspapers and are commonly cited by other media vehicles. They have a wider access to prominent figures and thus have a more direct influence not only on media but also on the public opinion of these issues. As Elisabeth Noelle-Neumann explains (1991), individuals look at the opinions of others on a particular topic, and tend to be silent and conform to the prevailing opinion of society if their personal opinion differs. The evaluation, in turn, is based on two sources: direct observation of daily interactions with other individuals and indirect observation through mass media, whose major influence in the field is exerted precisely by the vehicles that are commonly cited by other vehicles.

The specific time frames were chosen for this paper because the first period (2000-2005), which focuses on themes of prostitution and sex trafficking in the community, coincides with the second wave of Brazilian immigration, and the second period (2010-2015) coincides with a moment when the community was decreasing, as a result of the economic crisis. As Jorge Macaísta Malheiros (2007) explains, the Brazilian community has been growing since the 1980s, however, it has been growing at a staggering rate as of 1999, and this influx presents considerable differences in relation to the first wave.

The first time period was composed of mostly the qualified workers (mainly computer workers, publicists and dentists) and 
people that didn't work, while the second time period was composed of a much higher number of people, many of whom were younger and female and it included mainly those who had not attained higher education. However, due to the 2008 world crisis and its strong effect on the Portuguese economy, the Brazilian community declined between 2011 and 2016, as noted in the annual statistical reports produced by the Portuguese Immigration and Borders Service (SEF) ${ }^{4}$.

We looked at all editions of Público and Expresso in order to observe how the image of Brazilian immigrant women regarding prostitution and sex trafficking was built in those newspapers' discourse, and to see if the same pattern remained in the second analysis period, years after the "Mothers of Bragança" case and with the Brazilian community still declining. We observed that in the first period, the Expresso newspaper presented seven news pieces on prostitution and sexual trafficking of Brazilian immigrant women. With the exception of the first text from 2000, "Clients help dismantle trafficking in women" (6/17, p.6), all the others emphasize the "Brazilian" nationality of most or all the women involved in the reported cases of prostitution and trafficking. The Público newspaper, in turn, published five news pieces on these issues and, similar to its counterpart, only one text from 2001 , "SEF detains 30 illegal foreigners in Alto Minho brothels" (8/05, p. 19) which identified Brazilians as one of the nationalities of the detained group of women ${ }^{5}$.

We observed that, particularly after the "Mothers of Bragança" case, this identity label found in the discourse is indicative, but it also comes from discursive strategies of generalizing and excessive lexicalization where the term "Brazilian", when used repeatedly to refer to women who prostitute themselves, highlights the underlying ideology for their employment. As Peter Teo explains (2000), the ideological dimension of this strategy lies in the fact that its constant use means it becomes increasingly unquestioned and naturalized, which is in line with the process of metonymization of the image of Brazilian immigrant women who prostituted themselves during these time spans.

The strategy behind using excessive lexicalization (which is obvious in texts where immigrants were characterized based on information that is irrelevant towards understanding the discourse, such as the "childish laughter and talk" of women in brothels, or the boyfriend of an interviewee, herself a victim of sex trafficking, not being the father of her child) has a pejorative effect because these details allude to a 
kind of deviation of social norms and expectations. Its use "“[...] reflects perceptions and judgements from the essentially biased [Portuguese] standpoint of such cultural norms or social expect " (Teo, 2000, p.21).

In the second time period the Expresso newspaper published two news pieces on the prostitution and sex trafficking of Brazilian immigrant women and the Público newspaper published five ${ }^{6}$, in fact, as of 2010, not only were there fewer texts on the subject, but also fewer stereotyped representations of Brazilian immigrant women, although not entirely eliminated from the discourse. For example, the 2010 report in the Público "The Red Nights of Two SEF Inspectors" (10/2, pp. 4-5) featured the following cover story: "Judgment - SEF Inspectors, illegal Brazilian women, and raids", which not only employs a generalizing strategy by erroneously indicating that Brazilian immigrant women would be the sole beneficiaries of the inspectors' criminal scheme, but also introduces a problematic framing by highlighting their identity in the title of the text. As Robert Entman (1993) explains, news framing essentially involves operations of selection and salience, so framing corresponds to the act of selecting some aspects of perceived reality and making them more eye-catching. This leads us to question why, or for what underlying ideological reasons, the only women identified in the criminal activity were of Brazilian nationality.

Of note is the fact that Público's text from 2010, "In the first person - I paid eight thousand dollars to the people who brought me to Europe" (06/30, pp. 4-5), and Expresso's text from 2012 "Bodies that tell stories" (08/18, pp. 28-38), correspond to profiles of Brazilian immigrants who voluntarily decided to come to Portugal to prostitute themselves, which we identify as examples of the popularization of news centered on the human face. As Correia (2008) explains, the trend expresses new perspectives on the identity of minorities, perhaps because they believed it would be a fun fact and contain a hint of anthropological intrigue. In the texts cited above, the 'agentivity' of individuals is valued, yet by limiting the discourse to individual accounts, they fail to address the ambivalences that are typical of this same agentivity because, in many cases, the same desire to emigrate for the purpose of prostituting is heavily connected to exploitation schemes and economic poverty.

Also noteworthy is the fact that the characters in both this 2010 text from Público and the 2003 Expresso report, "The gigolo profession" (Única, 7/6, pp. 81-88) are Brazilian immigrant men. This suggests that the sexualized social representation of Brazilian 
women has also spread to Brazilian men, which would foster a sex trade aimed at both men and women.

In the following section we shall present a more detailed look at a few texts.

\section{Analysis of news}

The first and most extensive news piece we found about the problem of Brazilian women and sex trafficking was "Brazil and Portugal Fight", featured in the December 15, 2000 issue of Público (p.20). The information in this text is structured around the Palermo Protocol conference, but was not limited to the issue of human trafficking as it also discussed ways to combat drug trafficking and illegal money laundering.

Looking at the thematic structure (Van Dijk, 2002) we noticed that the theme the reporter chose to focus on was trafficking in persons associated with prostitution. We divided the text into the following topics, in the order they appeared:

(1) Trafficking in human beings is the third most lucrative criminal activity in the world.

(2) One of its main activities, prostitution, occurs frequently between Brazil (country of departure) and Portugal (country of arrival for victims).

(3) Both countries are committed to combating trafficking in persons.

(4) The trafficking works in the following way: women are brought illegally into the country on the promise of employment, but when they arrive their passports are confiscated and they are subsequently forced to prostitute themselves.

(5) The Palermo Conference aims not only at coordinating inter-state efforts to combat trafficking in persons, but also drug trafficking and illegal money laundering.

(6) Brazil, like many other participating countries in the Palermo Conference, has not typified the crime of trafficking in persons.

We then say that the superstructure of the report is composed in the "summary" (made up of the title, subtitle and lead) by highlighting the fight waged by Portugal and Brazil to stop the trafficking of people destined for prostitution, and the "background" contextualizes how this criminal activity takes place, what the stances of Portugal (receiving country) and Brazil (leaving country) 
are globally, and how the Palermo Conference intends to combat this type of trafficking with the other types of crimes it deals with.

Particularly noteworthy is the fact that in two occasions the verb "export" is used to characterize Brazil's position on the map of human trafficking routes. The verb appears in quotation marks in a sentence written underneath the image, it reads: "Brazil 'exports' about 75,000 women a year to prostitution circuits". Further on, in the body of the text, there is a statement that claims Brazil ranks among the top six countries in the world that "export" (quotations added) the most women to the international prostitution market.

We find the use of this verb - usually used to refer to products - problematic when it is associated with women as it accentuates the dehumanization of Brazilian women who are victims of trafficking for prostitution. This verb combined with the image accompanying the report of a woman wearing a bikini on a beach, admiring and touching her buttocks, with the internationally recognized "Sugar Loaf" from Rio de Janeiro in the background (which makes it clear where the photo was taken), reinforces the objectification of Brazilian women found in the text.

We did note, however, that this article on Brazilian prostitution in Portugal characterizes the activity as a form of slavery (as evident in the subtitle). Yet when it came to the "Mothers of Bragança" movement there was less journalistic focus on the exploitation and crimes which immigrant prostitutes are subjected to (Correia, 2014).

We note that the article "Sex and the Family," (pp. 64-70), from the May 10, 2003 issue of Única - a magazine pullout for Expresso - follows a similar framework as the one used in the "Mothers of Bragança" manifest written by the mothers, contrasting the family (represented through the image of the mother) with the image of Brazilian women, who are described in that manifest as a great threat to society. The report also adopts a dichotomous theme of morality; the family versus the immorality of Brazilian prostitutes. Journalistic texts always present a theme, a central idea, which is supported by the information around it. "Because of this structuring function, a theme is also called a frame" (Pan \& Kosicki, 1993, p.59).

This dichotomy in framing, with an underlying moralistic perspective, is evident when looking at the "summary" of the report. The cover page reads "Attack on traditions", followed by the subtitle: "Bragança is turned on its head. All in the name of family. The brothel girls are the target". The text has the suggestive title of "Sex and family", accompanied by the subtitle: "The 'Mothers of Bragança' are 
fed up with the Brazilian working girls. They signed a petition to expel the illegal ones. They say they destroy marriages".

Using the headlines "35 euros for half an hour", "Hope in Lula", "Beaten for talking to the newspapers", "What l'm doing here" and "Spells with flowers", the report describes the following trajectory: it starts by describing the brothels in Bragança, the women who work in them, and how they perform their activities. It goes on to characterize Brazilian women, describing them as women from very humble origins who long to return to Brazil and are not proud of their activities in Portugal. The report then focuses on the members of the movement, the "mothers", and ends by investigating the accusation from the "mothers" that Brazilian women use spells and in order to seduce their husbands.

We identified some inconsistencies here because the framing of the "summary" adopts a moralistic tone by relating Brazilian women to sex, perversion of traditions, and being opposed to the institution of family, yet there are citations from Brazilian women within the text that portray them as victims. For example, "II would like to keep working in a beauty salon. But it depends on the salary. I heard that they don't pay well here...', she answered. Her eyes filled with tears" and "Scream. 'My God! What am I doing here? Why am I not in Brazil with my daughter?' Another girl calms her down".

They are portrayed as victims only of the circumstances of life and/or the socioeconomic situation in Brazil since at no time do the terms "trafficking in persons", "encouraging prostitution" or other similar terms appear, despite identifying some parts of the report that would enable such an approach. We say this because one of the passages in the text states that only one out of the 12 women working in the brothel that was visited by the reporting team had a contract. Further in the report it also states that Brazilian women usually arrive with tourist visas and not working visas, meaning once the threemonth validity of the tourist visa expires, they become illegal.

The victimizing representation is highlighted in another report published in October of that same year in which Única turns its attention to Goiânia, a city in the interior of Brazil where many of the Brazilian women who came to prostitute in Portugal came from. Similar to the framing in the previous report, this article explores the difficult living conditions of Brazilian women who came to Portugal and, with no alternatives to a life of hardship, go down the path of prostitution.

The characterization of women as victims is evident in the article's title "At the Root of Hardship" (10/25, pp.83-94), in its subtitle 
"[...] Two women tell their stories of how they escaped the nightmare" (emphasis added), as well as in some of the quotes from the figures in the story, such as "I ruined my life" and intertitles like 'Sex slaves' and 'In the hands of the mafia'. It summarizes the precarious living conditions in Goiânia: "73\% of girls between 13 and 17 years of age have a child. Every 15 seconds a woman is violated" (original emphasis).

However, the style and rhetoric of discourse appears slightly ambiguous in terms of characterizing Brazilian women because, as the text clearly states, not all of them went to Portugal unaware of the activity they would end up getting involved in. For example, one of the characters in the report, Denise, starts her story with this introduction by the reporter: "Those who want to be deceived are deceived: even after all this news, Denise has not even suspected her friend's small talk [...]". The text also makes the following judgment about the troubled and unfortunate life of another Brazilian woman who had prostituted herself in Portugal:

The life of this Brazilian woman looks like a runaway train, it never stops derailing. She has never learned from her mistakes. And when she became a professional prostitute for the second time, she got involved with another Portuguese man.

However, the image of this Brazilian woman as a victim of sex trafficking is clearly challenged the following year in a Público interview with Isabel Burke, an SEF inspector who was transferred to Brazil to combat trafficking and illegal immigration. By the title alone "Most Brazilian Prostitutes 'know what lies ahead"' (7/23/4, p.27) a reader, without having to actually read the text, can easily figure out what the interview will be about: the idea that Brazilian prostitutes in Portugal knew what they were getting into when they immigrated.

The information provided by the inspector is framed in the subtitle: "The Immigration and Borders Service inspector transferred to Brazil to combat illegal immigration dispels the 'myth' of trafficking victims being forced to prostitute themselves". We see the quotation marks around the noun as a weak stylistic strategy to legitimize the inspector's judgment because Burke had said that most women knew what they were getting into, but there were those who - even if the minority - were deceived or misled, which demonstrates the inappropriate use of the noun.

What we see from the interview is that rather than dwelling on whether or not Brazilian women are misled, the reporter's questions and the inspector's answers fall in line more with the definitions of global human trafficking and the perspective of Portuguese legislation at the time. Burke describes this legislation: 
What we have - and what we consider to be trafficking, but which Americans do not - are organized networks that bring perfectly controlled immigrants from their home country to their destination country. Even though they walk on the street and can change workplaces, their documents are registered and they have to pay a monthly or weekly fee to work.

In 2005 we turned our attention to two other reports, one from Expresso and one from Público. The text "Brothel without Borders" (Única, 5/07, pp. 50-60) begins by highlighting the initial trial proceedings of a brothel businessman in order to speak specifically about the prostitution of Brazilian women, using a framing which focuses on the legal perspective of the phenomenon. This is particularly evident from the inclusion of Teófilo Santiago, the senior coordinator of Criminal Investigation at the time, who emerges from the text as an authoritative source of information.

The article begins by briefly commenting on the arrest and trial of Alfredo Palas, shortly after this information, Santiago explains the reason for the predominance of Brazilian women in this profession, who are more numerous than the Eastern European women who arrived in Portugal in the late 1990s: "Many of the women from the east seem to be protected by mafias in their home countries, which makes it difficult for those who want to exploit them. Brazilian women have nothing, and most of them are illiterate".

We point out that the premise, in the way it was delivered, differs in tone and form from what Burke used to explain the same hegemony:

\footnotetext{
The Brazilian women took over this market. They speak the language, they're affectionate, friendly. I can't explain it, but I think it has to do with what Portuguese men like and the kind of money Eastern women can make in other European Union countries...
}

Even though the report contains Brazilian characters who claim not to be victims and who, in large part, had already prostituted themselves in Brazil, their exploitation is evident from the stories they tell. For example, when introducing Tania, the report states that the employer was withholding her passport, which he would only return to her if she reimbursed him for travel expenses, around 4,500 euros. The reporter includes the woman's explanation for not being able to leave; “'Unless I give him this money, I cannot leave. Then, I'll go wherever I want', then goes on to explain: "But it's not easy to pay off the debt. Apart from the debt, she has to pay another 45 for the room - and in order to pay for the room she has to do at least two 'jobs' a day".

A report from the June 8, 2005 edition of Público entitled "Businesswoman of the night trial starts today in Famalicão" (p.24) 
covers the same topic that the Única text covered, albeit in a more limited scope. We see this as a reflection of the many police investigations that occurred two years prior with the "Mothers of Bragança" case and the trials that followed in 2005. However, we find the inclusion of the businesswoman's nationality in the subtitle problematic ("In a world dominated by men, one Brazilian woman establishes herself in Baixo Minho") mainly because when the article discusses the gang which she was leader of, it does not disclose the nationality of anyone else.

In that regard, this statement in the discourse is not only unnecessary, but also has an underlying ideology behind it. As Teun van Dijk (2002) explains, many ideological implications appear not only because so little is said, but also because so much of what is said about news actors is irrelevant. "A well-known example of this in minority stories is the use of irrelevant racial and ethnic labels in crime news" (p.114).

There is also a small box in this article containing a short interview with Isabel Burke who disagrees with the insistence, present in the interview made one year before, that the Brazilian women knew what they were getting into. She reiterated the observation in this interview, but also made it clear that women were still victims.

It is quite difficult to get evidence for this type of crime. The evidence is basically testimonial. And most women don't consider themselves victims because they almost always know what they are getting into. Now, what often happens is that they are misled as to the conditions under which they will work. Even still, they do not complain. It is important for people to realize that they are exploited. [...]

In the second period which we selected texts from (20102015), we looked at two reports from Público, chosen for their differing recommendations on how to deal with the problem of prostitution (it is interesting to note that these reports were published in the same newspaper at roughly the same time). In "Prostitution is moving increasingly closer to village streets" (8/11/12, pp. 2-3) - unlike the standard approach to most of these kinds of articles, this one did not indicate the nationality of those women who were prostituting on the highway roadside just outside the parish of São Pedro da Torre. As one of the passages in the article reads: "Manuel Afonso even contacted the Immigration and Borders Service. Some came from overseas, but none are illegal".

Even though the news about women offering their services on a public highway instead of in apartments (which is what normally occurred in that region) is framed from a vaguely moralistic perspective, showing how this specific kind of prostitution created discomfort for the 
residents of the parish, as evident in its subtitle: "Half a dozen prostitutes are enough to disturb São Pedro da Torre in Valencia", the report also offers alternative ideas as to why some prostitutes migrate to the streets.

That same subtitle ends by saying: "There are those who exchange apartments for the streets due to a lack of clients" and offers the following reason for the recent influx of prostitutes on the streets: the economic crisis that plagued the country also weakened the sex trade. This report also contains a box which reads "Fewer clients and fewer Brazilian women to work". This report was based on information obtained from non-governmental organizations that made up the Sex Work Network (RTS) and explains how the economic crisis had affected prostitution, leading more people to prostitute themselves for longer hours. It also led to a decrease in the number of Brazilian women in the profession due to the strength of the Brazilian economy at the time and the decision of many of them to return to their home country.

Paulo Anjo, the coordinator of the non-governmental organization Associação Existências for the municipalities of Coimbra, Mealhada, Condeixa, Figueira da Foz and Aveiro, speaks of a rebalance after the domination of Brazilian women: "They are returning to Brazil, but the number of Portuguese has increased".

Included on the front pages of the newspaper, under the label "Feature", what we observe in the content and framing of the article is that, with the economic crisis worsening, with more people prostituting in the streets, and with the marked decrease of Brazilian women and the increase of Portuguese women in the profession, the discourse surrounding prostitution becomes one of a social problem derived from the economic crisis and the lack of perspectives in the country.

However, the obvious decision for the text to not disclose the nationality of the prostitute women is not something that other texts follow, for example, the article "In Quinta do Grilo sin pays the IMI", published in the January 13, 2013 edition of Público (pp. 20-21). The conflict in Bragança was due to the fact that countless husbands were going to brothel bars and arriving home late and drunk; the problem in Quinta do Grilo was the presence of female prostitutes who worked out of neighborhood apartments, which began to bother residents when said prostitutes began to expose themselves and wear revealing clothing in the apartment windows and balconies.

However, the controversy from the previous decade had unfolded in a mostly moral context, with wives and members of the Catholic Church arguing against prostitutes and preaching the 
sanctity of marriage, etc. This, as noted in the previous report, was also an issue of commerce because neighborhood housing began to lose value once prostitutes began to offer their services, which also attracted noisy clients who, according to the report, used to shout profanities and masturbate in the street.

The dichotomy of moralism and a commercial issue is summarized in the 2012 report from a resident who lived near the entrance of São Pedro da Torre, where women would stand on the road waiting for customers: "I am unhappy. The houses lose value. Sometimes I'm in the garden and it's unpleasant the way they look at me [men passing by in their cars]"'. This dichotomy is evident in the subtitle of this report on prostitution in Quinta do Grilo:

Prostitutes serving clients in apartments is not exclusive to Quinta do Grilo, in Viseu. What's different is that Brazilian women appear half-naked in the windows, creating a moral problem among their neighbors. Or is it rather a trade war? (emphasis added)

While the moral side to this report is quite evident, especially in the title and subtitle, in the 2012 text this appear vaguely on quotes taken from one of the interviewees, with the report focusing on the social and economic reasons for women leaving their apartments and prostituting in the streets. We understand the diversity because media vehicles, far from being mere ideological supports of hegemonic systems of thought, "affirm themselves as plural places for producing strategies that aim to reformulate the social process" (Correia, 2008, p.151).

Interestingly, when comparing the report with the journalistic materials analyzed by Correia (2014) about prostitution in Quinta do Grilo, we noticed that some information was missing, such as the existence of a group called "Mães de Viseu" (Mothers from Viseu), as well as the report itself containing disparate information. For example, the report published by the TSf's radio channel website states that the vast majority of women were illegal immigrants; however, the Público report states:

\footnotetext{
Whenever one of the Brazilians is stopped in the street, they always present legal identification. "They say they don't have it on them, but then a friend appears with their papers. It is always the same story. The truth is that those who bring them from Brazil keep their documents so they do not run away without repaying the "debt" [from an anonymous police source interviewed for the article].
}

The author also cites a report from the SIC television channel in which the problem is framed by a security plan, discussing 
the illegality involved in the exploitation of prostitution and the encouragement of immigration for the purposes of sex trade. Despite the fact that the passage above certainly indicates that pimps are controlling the women who prostitute themselves in the neighborhood, the issue is not addressed at any time in the Público text. However, certain social representations about Brazilian women employed ten years earlier still remain.

The first that stands out is the subtitle, which uses a generalization strategy by continuously describing the neighborhood prostitutes as "Brazilian women" and leads us to the ideological consequence of this: its adoption in an increasingly less questionable and more naturalized way (Teo, 2000). Prostitutes are referred to as "Brazilian women" six times in the article, despite the following excerpt: "In addition, young girls, almost all Brazilian, literally call men [...]" (emphasis added).

We also draw attention to the use of sensationalist language, evident in the title (which contains the word "sin") and in the third paragraph of the article: "There are serious problems. Personal ruin, broken families. Extreme hatred and unbridled passions. But everything is calm in Quinta do Grilo". The theme of the report rests on the dichotomy of presenting the problem to residents as both moral and commercial inconvenience; the former being explored in two ways: through sensationalist language and describing prostitutes as "Brazilian women".

\section{Final considerations}

The collective imagination in Portugal about Brazilian women dates back to colonial times and the exotification of their sexuality. The stereotypical image usually appears when the characters of a news story are Brazilian; however, by the end of the twentieth century news on the trafficking and prostitution of Brazilian immigrant women had become more frequent as a result of the economic prosperity experienced in Portugal and the influx of a large number of Brazilian immigrants. This ended up finding its way into journalistic discourse through the framing it was given and the rhetorical and stylistic choices adopted to characterize Brazilian women.

In this regard, the "Mothers of Bragança" movement is seen as significant because, by presenting itself publicly from the bias of Christian morality, and by contrasting the nuclear family with Brazilian prostitutes, it influenced a journalistic discourse which was based on 
the exotification of Brazilian women and the extensive use of tabloid language and xenophobic rhetoric. However, as the years went by and criminal investigations were conducted on those who managed and owned the brothels, coverage changed and, particularly with the issue of immigrant prostitution covered in the Público and Expresso newspapers, encompassed a framing that focused on "pimping", "trafficking in persons" and "illegal immigration".

Nevertheless, when considering the material analyzed for this paper, we do not really see that there has been any remarkable evolution in terms of the coverage this issue has received. On the contrary, instead of taking a linear path over the years which would see a stereotypical approach give way to a more consistent treatment of the problem, it has taken an erratic path, one where the coverage oscillates between discourse that focuses on sensationalism and discourse that focuses more on discussing the different aspects that surround it, which are: the illegality of exploiting prostitution coupled with the autonomous decision of some individuals to practice it and, as is the case for many of the women, a result of economic and social hardships.

\section{NOTES}

1 Information available at: www.state.gov/wp-content/uploads/20 19/06/2019-Trafficking-in-Persons-Report.pdf

2 The interviews were conducted in 2018 as a part of the doctoral research at the basis of this article. $O$ Ninho is a non-governmental organization that works with women in prostitution. ComuniDária is a non-profit organization that fights for the rights of immigrants who work in domestic services and prostitution.

3 More information is available at: www.otsh.mai.gov.pt/wpcontent/uploads/REC-Cartao_Sinalizacao_Vitimas_Trafico_ Humano_v2018.pdf

4 More information is available at: sefstat.sef.pt/forms/relatorios.aspx

5 The news pieces identified in Expresso for the first time period were: "Clientes ajudam a desmantelar tráfico de mulheres" (06/17/00, p.6), "O sexo e a família" (Única, 05/10/03, pp. 64-70), "Profissão gigolô" (Única, 06/07/03, pp. 81-88), "Na raiz da miséria” (Única, 10/25/03, pp. 82-94), “Alterne sem fronteiras” (Única, 05/07/05, pp. 50-60), 
"SEF e juíza às avessas" (11/01/05, p.16) and "Tráfico de mulheres em discussão" (12/10/05, p.18). In Público these news pieces were: "SEF detém 30 estrangeiras ilegais em casas de alterne do Alto Minho" (08/05/00, p. 19), "Brasil e Portugal na luta" (12/15/00, p.20), “'Mães de Bragança' acusam brasileiras de provocar onda de loucura na cidade" (05/01/03, *local Porto), "A maior parte das prostitutas brasileiras 'sabem para o que vem"' (07/23/04, p.27), and "Empresária da noite começa a ser julgada em Famalicão” (06/08/05, p.24).

6 Expresso: "Corpos que contam histórias" (Revista, 08/18/12, pp. 28-38) and "General oferecia prostitutas em Lisboa" (11/02/12, p.12). Público: "As noites vermelhas de dois inspectores do SEF" (caderno P2, 02/10/10, pp. 4-5), "Para elas, prostituição é trabalho como outro qualquer" (caderno P2, 06/02/10, pp. 6-7), "Na primeira pessoa - Paguei oito mil dólares às pessoas que me trouxeram para a Europa" (caderno P2, 06/30/10, pp. 4-5), "Prostituição está cada vez mais perto das ruas da aldeia" (08/11/12, pp. 2-3) and "Na Quinta do Grilo o pecado paga IMI" (01/13/13, pp. 20-21).

\section{REFERENCES}

Bosco, F. (2017). A vítima tem sempre razão? Lutas identitárias e o novo espaço público brasileiro. São Paulo: Todavia.

Brito, B. M. J., \& Rosas, F. (1996). Dicionário de História do Estado Novo (Vol. I). Lisboa: Bertrand Editora.

Castelo, C. (1988). O modo português de estar no mundo. O lusotropicalismo e a ideologia colonial portuguesa (1933-1966). Porto: Edições Afrontamento.

Correia, C. J. (2014). Dez anos depois de Bragança, a representação da mulher brasileira nos media. Verso e Reverso, 28(69), 186-192. Retrieved from revistas.unisinos.br/index.php/versoereverso/article/view/ver.201

Correia, C. J. (2008). Identidades e Realidades Múltiplas: Os Estranhos no Meio de "Nós". In P. J. Esteves (Ed.), Comunicação e Identidades Sociais (pp. 131-154). Lisboa: Livros Horizonte.

Cunha, I. F. (2005). A mulher brasileira na televisão portuguesa. In A. Fidalgo \& P. Serra (Eds.), Actas do III Sopcom, VI Lusocom e II Ibérico (vol. III) (pp. 535-553). Covilhã: Universidade da Beira Interior.

Craveiro, C., \& Carvalho, C. (2017). A um passo da branquitude: o que dizem os corpos das mulatas brasileiras. Interfaces Científicas - Humanas e Sociais, 6(2), 65-76. DOI: 10.17564/2316-3801.2017v6n2p65-76 
Duarte, M. (2012). Prostitution and Trafficking in Portugal: Legislation, Policy, and Claims. Sexuality Research and Social Policy, 9(3), 258268. DOI: $10.1007 / \mathrm{s} 13178-012-0093-2$

Entman, R. M. (1993). Framing: Toward Clarification of a Fractured Paradigm. Journal of Communication, 43 (4), 51-58. DOI: 10.1111/ j.1460-2466.1993.tb01304.x

Feldman-Bianco, B. (2001). Brazilians in Portugal, Portuguese in Brazil: constructions of sameness and difference. In B. Feldman-Bianco (Ed.), Colonialism as a continuing project: The Portuguese Experience (pp. 607 -650). Identities: Global Studies in Culture and Power.

Freyre, G. (2003). Casa grande \& senzala (48 ed.). São Paulo: Global.

Malheiros, M. J. (2007). Os brasileiros em Portugal - a síntese do que sabemos. In J. M. Malheiros (Ed.), Imigração brasileira em Portugal (pp. 11-38). Lisboa: Alto Comissariado para Imigração e Diálogo Intercultural - ACIDI.

Machado, I.J. R. (2003). Cárcere público: processos de exotização entre imigrantes brasileiros no Porto (doctoral dissertation, Universidade Estadual de Campinas). Biblioteca Digital Unicamp.

Hall, S. (1990). Cultural identity and diaspora. In J. Rutherford (Ed.), Identity: Community, culture, difference (pp. 227-237). London: Lawrence \& Wishart.

Lippmann, W. (1998). Public Opinion ( $2^{\circ}$ ed.) New York: Macmillan.

Moscovici, S. (1988). Notes towards a description of Social Representation. European Journal of Social Psychology, vol. 18, $211-$ 250. DOI: 10.1002/ejsp.2420180303

Noelle-Neumann, E. (1991). The Theory of Public Opinion: The Concept of the Spiral of Silence. Annals of the International Communication Association, 14(1),256-287.DOI: 10.1080/23808985.1991.11678790

Padilla, B. (2007). A imigrante brasileira em Portugal: considerando o género na análise. In M. J. Malheiros (Ed.), Imigração brasileira em Portugal (pp. 113-134), Lisboa: Alto Comissariado para Imigração e Diálogo Intercultural - ACIDI.

Pan, Z., \& Kosicki, M. G. (1993). Framing analysis: An Approach to News Discourse. Political Communication, 10, 55-75. DOI: 10.1080/10584609.1993.9962963

Pais, J. M. (2010). "Mães de Bragança" e Feitiços: Enredos Luso-Brasileiros em Torno da Sexualidade. Revista de Ciências Sociais, 41(2), 9-23. Retrieved from www.periodicos.ufc.br/revcienso/article/view/455

Piscitelli, A. (2008). Interseccionalidades, categorias de articulação 
e experiências de migrantes brasileiras. Sociedade e Cultura, 11(2), 263-274. DOI: 10.5216/sec.v11i2.5247

Santos, B. S., Gomes, C., \& Duarte, M. (2009). Tráfico sexual de mulheres: Representações sobre ilegalidade e vitimação. Revista Crítica de Ciências Sociais, n. 87, 69-94. DOI: 10.4000/rccs.1447

Simões, R. B. (2018). News Media Power and Public Policy: the mediatized construction of women trafficking for sexual exploitation. Brazilian Journalism Research, 14(1), 130-151. DOI: 10.25200/BJR. v14n1.2018.1039

Teo, P. (2000). Racism in the news: a critical discourse analysis of news reporting in two australian newspapers. Discourse \& Society, $11(1), 7-49$. Retrieved from www.jstor.org/stable/42888294

van Dijk, T. A. (2002). Cognição, discurso e interação. São Paulo: Contexto. van Dijk, T. A. (2005). Discurso, Notícia e Ideologia. Estudos na Análise Crítica do Discurso. Porto: Campo das Letras.

ESTER AMARAL DE PAULA MINGA. PhD in Communication Sciences from Nova University of Lisbon, with a thesis on contemporary representations of Brazil and Brazilians in Portuguese society. She holds a Master's degree in Communication and Semiotics, she is a journalist graduated from the Pontifical Catholic University of São Paulo and a researcher at ICNova (Nova Communication Institute). Her research focuses on the fields of public opinion, social representations and gender. E-mail: ester.minga@gmail.com 